\title{
RENAL WATER EXCRETION IN PREMATURE INFANTS ${ }^{1,2}$
}

\author{
BY HENRY L. BARNETT, JØRGEN VESTERDAL, 3 HELEN MCNAMARA, AND \\ HENRY D. LAUSON
}

\author{
(From the Departments of Pediatrics and Physiology, The New York Hospital, Cornell \\ Medical Center, New York, N. Y.)
}

(Submitted for publication July 28, 1952; accepted September 17, 1952)

It is generally believed that, after water ingestion, the young infant can neither dilute his urine nor increase the rate of urine flow as rapidly or as effectively as the adult $(1-4)$. Although several sound investigations (4-6) have demonstrated that the kidneys of newborn animals are relatively inefficient in this regard, there have been very few direct observations on these important functions in infants. The present investigation was undertaken, therefore, to compare the renal response of the young premature infant with that of the older infant and adult to ingestion of water.

\section{PROCEDURE}

Nine series of observations were made on a total of 8 normal subjects including one observation in each of 4 premature infants ranging in weight from 1.84 to $2.21 \mathrm{Kg}$. and in age from five to eight days, in one premature infant 36 days old and weighing $2.46 \mathrm{Kg}$., and in 2 adults, and 2 observations in one 18 -month-old infant. The premature infants were all receiving half-skimmed cow's milk formulas. All observations were made in an airconditioned metabolism unit in which the temperature and humidity were maintained at $23^{\circ} \mathrm{C}$. and 50 per cent respectively and the subjects were lightly clothed to prevent sweating. The technics used for collecting blood and urine samples in premature infants have been described (7) and the same catheterization-infusion technic was used in the older infant and adults. Because it was observed that in premature infants venipunctures affected the functions being investigated (see Comment) the following plan was followed: three to six hours after the infant's last feedings and after 12 hours of fasting and thirsting in the adults, an initial blood sample was drawn, the bladder catheter was inserted, and a pre-hydration urine-collection period was started. At this same time a polyethylene nasal tube was passed into the stomachs of

1 Presented in part before the American Pediatric Society at Old Point Comfort, Va., May 8, 1952.

2 Supported in part by a research grant from The Playtex Park Research Institute.

${ }^{3}$ Rockefeller Foundation Research Fellow in the Division of Medicine and Public Health, 1951-1952. Permanent address: University Clinic of Pediatrics, Rigshospitalet, Copenhagen. the premature infants and of the 18-month-old infant. The presence of the tube was well tolerated. After 1 to $11 / 2$ hours, the infants were given water via the polyethylene tube and the adults drank water in doses equal to $40 \mathrm{ml}$. per $\mathrm{Kg}$. for the premature infants, $30 \mathrm{ml}$. per $\mathrm{Kg}$. for the 18-month infant, and $20 \mathrm{ml}$. per $\mathrm{Kg}$. for the adults. Per $\mathrm{M}^{2}$, these doses of water were equivalent to 507 to $530 \mathrm{ml}$. in the infants, $640 \mathrm{ml}$. in the 18-month-old infant, and 639 and $734 \mathrm{ml}$. in the adults. Except for collecting urine samples, the subjects were left undisturbed for another 1 to $11 / 2$ hours, at which time a second blood sample was drawn.

The following measurements and calculations were made :

1. Glomerular filtration rate (GFR): estimated by creatinine clearances $\left(\mathrm{C}_{\mathrm{CR}}\right)$ calculated from creatinine concentrations of serum and urine measured by the method of Hare (8).

2. Concentration of osmotically active urinary solutes $\left(U_{s}\right)$ : estimated by summating the milliosmolar concentrations of sodium (9), chloride (10), potassium (9), urea (11), phosphate (12) and creatinine (8). The sum of these values equalled 89 to 96 per cent of the total milliosmolar concentrations estimated from depression of the freezing points.

3. Rate of excretion of urinary solutes $\left(\mathrm{U}_{\mathrm{s}} \mathrm{V}\right)$ : calculated as the product of $U_{s}$ and urine flow (V).

\section{RESULTS}

The effect of water ingestion on urine flow (V.) in the 4 young and one older premature infant and in the 2 adults is shown in Figure 1. A marked diuresis which began at approximately the same time after water ingestion was observed in all of the subjects. Corrected on the basis of surface area, ${ }^{4}$ however, the increase in $\mathrm{V}$ in the young premature infants was only about one-half as great as in the older premature infant and in the adults.

Changes in the concentration of solutes in the urine $\left(U_{S}\right)$ after water ingestion are shown in Figure 2. No difference was observed in the

4 Surface area of the premature infants was calculated by the formula $5.188 \times \mathrm{Wt}^{0.075}$ (13). Surface area of the older infant and adults was estimated from the nomogram of DuBois (14). 


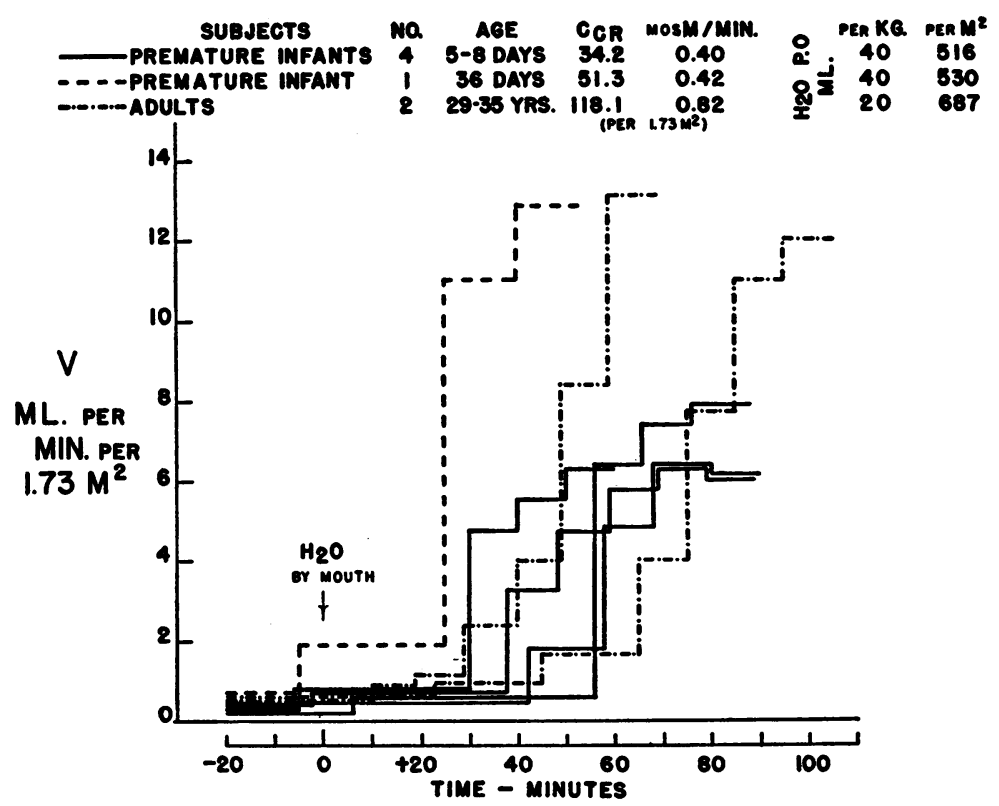

Fig. 1. Effect of Water Ingestion on Rate of Urine Flow (V)

rapidity with which or the extent to which the urine became diluted. Thus the lowest values for $\mathrm{U}_{\mathrm{s}}$ in the 5 premature infants ranged from 40.6 to 63.0 mosM per $\mathrm{L}$ (average 55.8) compared with values of 64.8 and 47.7 in the two adults and of 48.1 and 39.0 in two observations in the 18 month old infant.

\section{DISCUSSION}

Under the conditions of these observations, it would appear that the premature infant responds

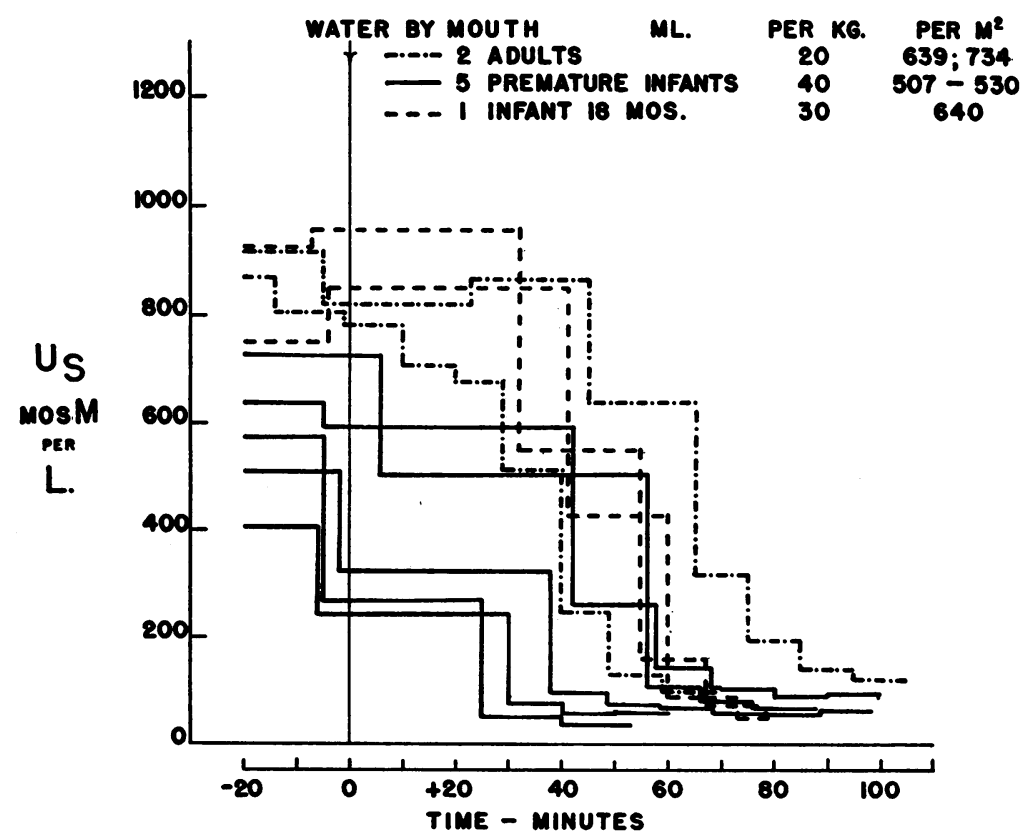

Fig. 2. Effect of Water Ingestion on Concentrations of Osmotically Active Urinary Solutes $\left(U_{\mathrm{s}}\right)$ 
to water ingestion by diluting the urine to the same minimum milliosmolar concentration as the adult, but that per $1.73 \mathrm{M}^{2}$ the infant attains a lower maximum rate of urine flow than the adult. This observation can be explained by at least two additional differences between the two groups of subjects. First, as shown in Figure 3, the glomerular filtration rate of water (GFR) in the premature infant was, on the basis of surface area, less than one-half that of the adult. Inasmuch as the maximum $\mathrm{V}$ per $1.73 \mathrm{M}^{2}$ in the premature infant was somewhat more than one-half that in the adult, it follows that a larger fraction of filtered water $\left(\mathrm{V} / \mathrm{C}_{\mathrm{CR}}\right)$ was excreted by the infant. In this sense, therefore, water diuresis was relatively more pronounced in the infant. Second, with GFR remaining constant, the degree to which V can be increased in the absence of antidiuretic hormone $(\mathrm{ADH})$ is determined by the rate of solute excretion $\left(U_{s} V\right)$. As shown in Figure 3,

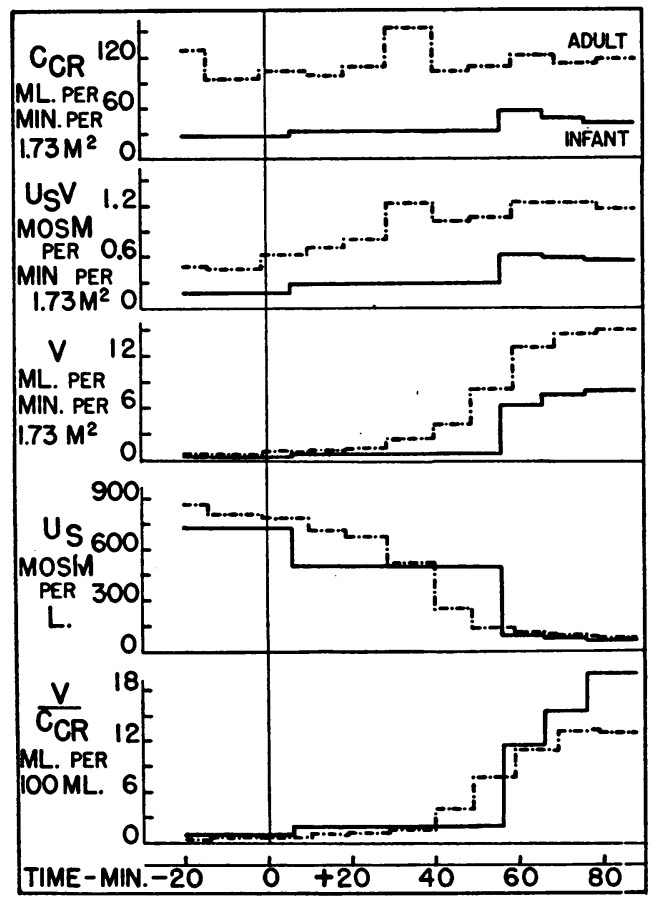

Fig. 3. Effect of Water Ingestion on Clearance of Creatinine ( $C_{C R}$ ), Rate of Solute Excretion $\left(U_{B} V\right.$ ), Rate of Urine Flow (V) Concentration of Urinary Solutes $\left(U_{g}\right)$ and Per Cent of Filtered Water ExCREted $\left(\mathrm{V} / \mathrm{C}_{\mathrm{cr}}\right)$ in a Premature Infant and in aN AdulT

Water was given at 0 time in doses equal to $20 \mathrm{ml}$. per $\mathrm{Kg}$. $\left(639 \mathrm{ml}\right.$. per $\left.\mathrm{M}^{2}\right)$ for the adult and $40 \mathrm{ml}$. per $\mathrm{Kg}$. $\left(527 \mathrm{ml}\right.$. per $\left.\mathrm{M}^{2}\right)$ for the infant.
$\mathrm{U}_{\mathrm{s}} \mathrm{V}$ per $1.73 \mathrm{M}^{2}$ was only about one-half as high in the premature infant as in the adult. For the premature infant to have attained a maximum $\mathrm{V}$ equal to that of the adult a greater dilution of the urine would have been required; this may not have been possible, even after larger water loads. Thus far, we have not achieved conditions in which the premature infant and the adult have, on the basis of surface area, equal rates of solute excretion which would permit exclusion of this variable in comparing their response to water ingestion.

\section{COMMENT}

The results presented here are at least in part contrary to the earlier observations of Aschenheim (15) and of Lasch (16) and to the general belief that the young infant is limited in his ability to dilute his urine and to increase $\mathrm{V}$ promptly following water ingestion. Any one or combination of several possibilities may account for the failure of earlier investigators to observe similar responses to water ingestion. A lower maximum $\mathrm{V}$ would possibly have been observed in the infants if the dose of water had been given on the basis of weight rather than of surface area. However, since comparisons between rates of urine flow and other kidney functions are almost always made on the basis of surface area (3) it seems reasonable that the dose should be calculated on the same basis. Secondly, if the infants observed here had been receiving breast milk rather than cow's milk, the rates of solute excretion would have been still lower; this would have further limited the increase in V. Finally, and perhaps most important, painful stimuli such as venipunctures may have a profound effect on $\mathrm{V}$ in the premature infant (17). In the observation shown in Figure 4, diuresis following water by mouth was interrupted for almost an hour as the result of a venipuncture. This type of response to pain has been observed repeatedly and suggests that in earlier observations $(15,16)$ inadvertent disturbances of the infant may have been responsible in part for failure to observe an increase in $\mathrm{V}$ following water by mouth. It is of special interest that the fall in $\mathrm{V}$ following venipuncture was accompanied, not by an increase in $\mathrm{U}_{\mathbf{s}}$, but by a marked reduction in GFR. Decreases in $\mathrm{V}$ which followed injections of pitressin, given without disturbing the infant through the 


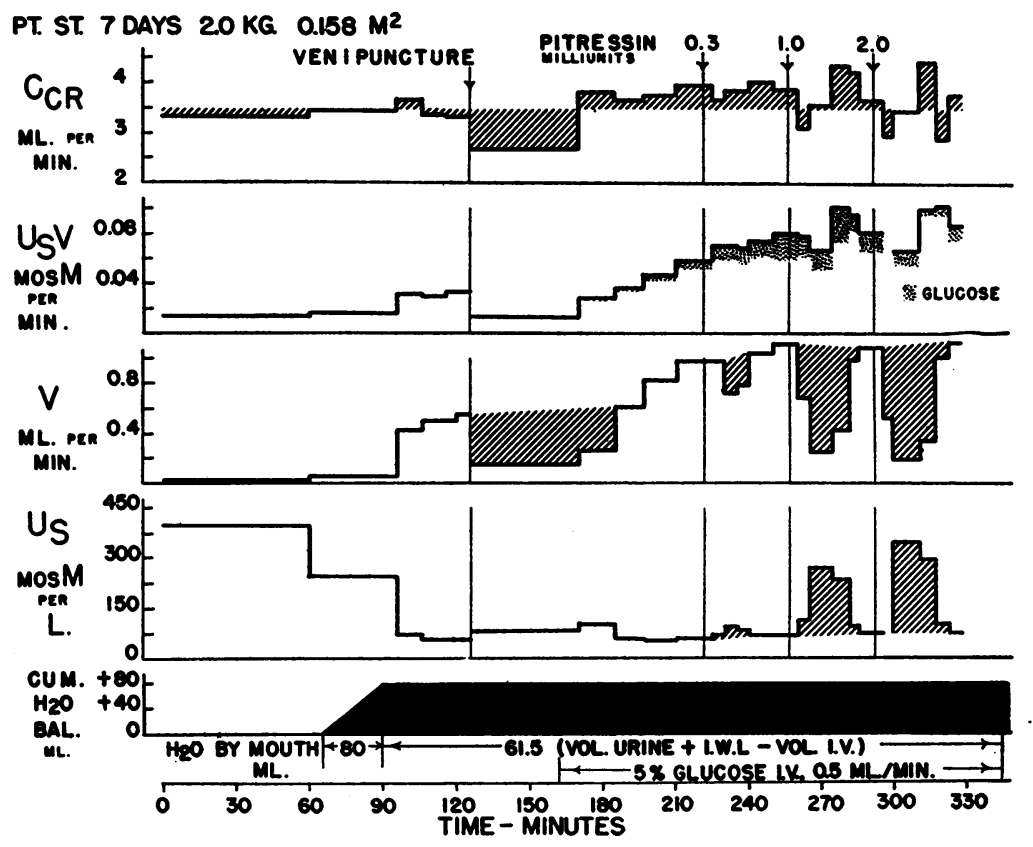

Fig. 4. EFfect of Venipuncture and Intravenous Injections of Graded Doses of Pitressin on Clearance of Creatinine (Cor), Rate of Solute Excretion ( $\mathrm{U}_{\mathbf{8}} \mathrm{V}$ ), Rate of Urine Flow (V), and Concentration of Urinary Solutes $\left(U_{s}\right)$ Following Water Ingestion in a Premature INFANT

tubing of a continuous intravenous infusion begun earlier, were, as expected, associated with a rise in concentration of urinary solutes and no real change in GFR.

\section{CONCLUSIONS}

The data presented here indicate that in comparison with older infants and adults, the young premature infant shows no limitation in his ability to dilute his urine following water ingestion. In the infant, maximum dilution of the urine occurs at relatively lower maximum rates of urine flow; this may be due to the fact that infants have, on the basis of surface area, lower rates of glomerular filtration and of solute excretion. Whether or not premature infants would show a similar response to water ingestion in the immediate postnatal period cannot be determined from these observations since the youngest premature infants ranged in age from five to eight days. The fact that a 36-day-old premature infant showed a response to water ingestion comparable in all respects to that of the adult, suggests a very rapid postnatal development of this function. A similar rapid development of concentrating ability has been reported by Pratt, Bienvenu, and Whyte (18).

A clinical implication which may be drawn from these results would appear to be that, per milliosmol of urinary solute, the young premature infant can excrete as much as $20 \mathrm{ml}$. of water. This value, which constitutes a definition of maximum renal water excretion, is the same for the infant as for the adult.

\section{ACKNOWLEDGMENTS}

We are indebted to Flora Hurwitz, R.N. for nursing and technical assistance and to Emily Matejka and Gladys Folkart for technical assistance.

\section{REFERENCES}

1. McCance, R. A., Renal physiology in infancy. Am. J. Med., 1950, 9, 229.

2. Smith, Clement A., The Physiology of the Newborn Infant, 2nd ed. Charles C. Thomas, Springfield, III., 1951.

3. Smith, H. W., The Kidney-Structure and Function in Health and Disease. Oxford University Press, New York, 1951. 
4. Heller, H., The water metabolism of newborn infants and animals. Arch. Dis. Childhood, 1951, 26, 195.

5. Adolph, E. F., Physiological Regulations. Lancaster, Pa., The Jaques Cattell Press, 1943.

6. McCance, R. A., and Wilkinson, E., The response of adult and suckling rats to the administration of water and of hypertonic solutions of urea and salt. J. Physiol., 1947, 106, 256.

7. Barnett, H. L., Hare, K., McNamara, H., and Hare, R., Measurement of glomerular filtration rate in premature infants. J. Clin. Invest., 1948, 27, 691.

8. Hare, R. S., Endogenous creatinine in serum and urine. Proc. Soc. Exper. Biol. \& Med., 1950, 74, 148.

9. Fox, C. L., Jr., Stable internal standard flame photometer. Analyt. Chem., 1951, 23, 137.

10. Van Slyke, D. D., and Hiller, A., Application of Sendroy's iodometric chloride titration to proteincontaining fluids. J. Biol. Chem., 1947, 167, 107.

11. Archibald, R. M., Colorimetric determination of urea. J. Biol. Chem., 1945, 157, 507.
12. Fiske, C. H., and Subbarow, Y., The colorimetric determination of phosphorus. J. Biol. Chem., 1925, 66, 375 .

13. Klein, A. D., and Scammon, R. E., Relations between surface area, weight, and length of the human body in prenatal life. Proc. Soc. Exper. Biol. \& Med., 1930, 27, 456.

14. DuBois, E. F., in Basal Metabolism in Health and Disease, 2nd ed. Philadelphia, Lea and Febiger, 1927, p. 124.

15. Aschenheim, E., Der Wasserversuch bei Säuglingen. Ztschr. f. Kinderh., 1919, 24, 281.

16. Lasch, W., Weiteres über den Wasserversuch im Säuglingsalter. Ztschr. f. Kinderh., 1923, 36, 42.

17. Vesterdal, J., and Tudvad, F., Studies on the kidney function in premature and fullterm infants by estimation of the inulin and para-aminohippurate clearances. Acta Paediat., 1949, 37, 429.

18. Pratt, E. L., Bienvenu, B., and Whyte, M. M., Concentration of urine solutes by young infants. Pediatrics, 1948, 1, 181. 